\title{
Revealing the Strengths and Weaknesses of a Corporate Portal
}

\author{
Kamla Ali Al-Busaidi \\ Sultan Qaboos University, Oman
}

\begin{abstract}
The role of corporate portal on consolidating an organization's internal and external information and knowledge repositories has been recognized by many organizations worldwide including academic institutions. The deployment of corporate portals has been growing in academia. This qualitative study examined the strengths and weaknesses of a corporate portal deployment at an academic institution based on faculty members' perceptions. The strengths and weaknesses analysis, which is a part of the SWOT (strengths, weaknesses, opportunities and threats) strategic analysis, is very useful to understand an organization's current position on the deployment of a corporate portal. This study illustrated that the deployment of a corporate portal at an academic institution is relatively successful. The results revealed that the strengths of the corporate portal are mainly related to information quality, system quality and recognized personal benefits; whereas the weaknesses are mainly related to system quality and few are related to information quality and support services quality. Furthermore, this examination provided some insights about success factors of corporate portal.
\end{abstract}

Keywords: Corporate Portal, Portal Strengths, Portal Weaknesses, University Portal.

\section{Introduction}

The role of corporate portal on consolidating an organization's internal and external information and knowledge repositories has been recognized by many organizations worldwide including academic institutions. Corporate portal is becoming a promising technology to improve the effectiveness and efficiency of the organization's information and knowledge management for many institutions. Corporate portals have made their way in academic institutions. They are getting a wide-spread attention in the academic world (Bajec, 2005; Li and Wood, 2005). Many organizations start their corporate portals deployment by implementing human resources functions on the internal portal, and then branch out to customer functions on the external portal (Rose, 2003). Corporate portals provide

several benefits for corporations, and their employees, partners and customers.

There are several vendors of corporate portals reported by (Raol et al., 2003; Rose, 2003). In the academic world, the majority of academic institutions are using Campus Pipeline; other software that are highly used are Epicentric, Oracle, and Home-grown software according to a recent research on the use of corporate portal in the academic world (Li and Wood, 2005).

The objective of this study is to examine the current position of a corporate portal deployment in academic institution by

Copyright (C) 2010 Kamla Ali Al-Busaidi. This is an open access article distributed under the Creative Commons Attribution License unported 3.0, which permits unrestricted use, distribution, and reproduction in any medium, provided that original work is properly cited. Author contact: Kamla Ali Al-Busaidi, e-mail: kamlaa@squ.edu.om 
examining its strengths and weakness. The internal analysis of an organizational project including information systems projects helps organizations on their strategic planning of organizational projects (Sabbaghi and Vaidyanathan, 2004). It is also a very useful tool to strategically analyze and understand an organization's current position on the deployment of corporate portal.

The information systems (IS) literature offers several frameworks to assess the internal characteristics of information systems that might be considered as internal strengths and weaknesses of a specific information system and contribute to its success. One of these popular models are DeLone and McLean's 1992 and 2003 IS success Models (1992, 2003). The 2003 IS success model indicates that the IS use and user satisfaction are determined by Information quality, system quality and service quality (DeLone and McLean, 2003). Additionally, the use of IS and user satisfaction result in net benefits. These resulted net benefits may further improve the use and the user satisfaction of an information system. The following sections discuss the background literature, research questions, research methodology, analysis and results of this study.

\section{Background Literature}

\section{Corporate Portal}

Corporate portal is a web-based technology that enables employees to have a single point of access to organization's internal and external data and knowledge repositories, and present it in a personalized view. It provides employees not only content space, a space to access and retrieve information, but also communication space and collaboration space to provide channels for conversations and support cooperative work tasks respectively (Deltor, 2000)

Based on Watson and Fenner (2000), the main features of corporate portals are: information gathering, categorization and organization, collaboration, search, distribution and publishing, personalization, life cycle management, auditing, analysis, expertise determination, and locating individual experts.

Aneja et al. (2000) provide a more comprehensive architecture of a corporate portal; a corporate portal includes internal and external information resources. Internal information resources include internal websites, collaboration products, documents, organizational knowledge bases, and data warehouses; whereas, external information resources may include external websites, external content, news and news feeds, and external services. According to Benbaya et al. (2004), portals provide users several features: core capabilities (collaboration, integration, publication, search, personalization and taxonomy), supportive capabilities (security, scalability and profiling) and web services. Thus, corporate portal provides rich support and capabilities for an organization's knowledge management.

\section{Strengths of Using Corporate portal}

Corporate portal has some recognized strengths. The main strengths of a corporate portal are its capabilities of categorization, integration, content publication and management, integrated search, personalization, goal- oriented interface and navigation and collaboration tools (Aneja et al., 2000). According to Gurugé (2002a), corporate portal increases corporate reaches, reduces operational costs, enhances corporate competitiveness through the ability to efficiently and cost effectively provides more information and services with this web mechanism, boosts customer loyalty by eliminating delays, frustrations, and inefficiencies, and improves and speeds up productivity, decision making and business processes through rapid access to relevant data sources and process streamlining. Corporate portal improves employees' productivity by improving corporate information access (Aneja et al., 2000). Portals provide an efficient access to relevant and accurate information and knowledge (Rainer et al., 2007; Turban et al., 2005).

In addition, several companies reported financial benefits from the use of corporate 
portals (Rose, 2003). Hewlett-Packard got $\$ 50$ million of savings in its first year of implementing a human resources portal. Likewise, Whirlpool got sales growth of $\$ 3$ billion by implementing a business to business portal. Also, Halliburton had increased sales by $\$ 10$ million and reduced support and selling costs by $\$ 280,000$ by implementing a portal to manage data from its application portfolio.

In conclusion, "through the methodical, stepby-step process of adopting portal technology within their organizations, these companies can expect greater overall efficiency, and increased bottom line, improved management and ultimately, employee and customer satisfaction" (Rose, 2003, p.70).

\section{Weaknesses of Using Corporate portal}

Despite, the importance and popularity of the portals, there are a number of identified weaknesses in the literature associated with its use and deployment.

According to Benbya et al. (2004), the factors that might affect the adoption of corporate portals are related to technical challenges such as system design, information quality, usability and segmentation; management challenges such as leadership, rewards system, cost effectiveness and strategy; and/or social challenges such as organizational culture, trust, commitment and satisfaction).

Research concluded that the weaknesses of portals are related to the content quality and relevancy, and change management (Norris and Duray, 2002); team management and integration (Roberts-Witt, 2000); and security (Rose, 2003). The security concerns are related to the current authentication tools of portal that depends on user names and passwords. Security, scalability, synchrony (keeping portal content up-todate), and speed are the vital issues for maintaining a successful corporate portal (Gurugé, 2002b).

In a recent study of universities in the USA and Canada, Li and Wood (2005) found that the biggest challenges of deploying and maintaining a campus portal are technical issues (integration and single logon), while the biggest challenges of corporate portal are behavioral issues (user acceptance and participation).

\section{Research Questions and Methodology}

\section{Research Questions}

The objective of this research is to assess the strengths and weaknesses of corporate portal at an academic institution. Strength and weaknesses analysis is the first part of SWOT, one of the tools that assist organizations on the strategic planning of organizational projects; it is also a very useful tool to strategically analyze and understand an organization's current position in any IT deployment (Sabbaghi and Vaidyanathan, 2004). It examines the benefits by looking at the strengths and the costs by looking at the weaknesses of deploying and using a corporate portal at an academic institution. From the perspective of strategic management, a good fit maximizes a firm's strengths and minimizes its weaknesses (Pearce and Robinson, 2003). Thus, from the perspective of corporate portal, a firm needs to reach a good fit plan that maximizes the strengths of the corporate portal and minimizes its weaknesses.

To reveal these research issues, three openended questions were developed. These research questions are as follows:

1. What aspects of the university portal do you use?

2. What are the strengths of using corporate portal?

3. What are the weaknesses of using corporate portal?

\section{The Investigated Organization \& System}

This pilot investigation examines the strengths and weakness of corporate portal in a public academic institution, Sultan Qaboos University (SQU), in Oman. The investigation includes faculty members (academic staff) who use the corporate portal. 
Based on the SQU portal documentation and website, the SQU portal aims to consolidate e-services for three types of users, students, faculty members, and administrative and technical staff. Visitors are also able to access this corporate portal. The SQU portal is a dynamic web-based electronic gateway on the university internal and external data resources. Information is personalized according to different types of users. Users can access the portal through the standard access authorization (username and password). Different types of users have different authorization access to the information and resources available in the portal.

The SQU portal includes several information sources and resources; they are applications and systems used by the university such as human resources system, library system, registration system; services and capabilities available in the portal such as appointments tables; and links to external services such as news feeds and anti-virus software sites. The main home page can be accessed by everyone and it provides links to general services data and general information such as the university's scientific publications, universities magazines, staff publications; main library resources, vacancy notices and other useful links. The main home page also has login space to allow users including instructors to login into their personal pages using access authorization (usernames and password).

The faculty members', which represent the sample of this study, portal view include three main sections: general section, academic section and services section.

In the "general section", the faculty members can:(1) view information about coming training, workshops, conferences, and other university activities; (2) use and search the university on-line telephone directory; (3) view some of the university regulations; (4) link to external websites such as antivirus companies and hardware companies.

In the "academic section", faculty members can: (1) find information about their academic work (i.e. class details and time tables); (2) find information about the students registered for the courses and send email to them; (3) find information about the students under their supervision and send email to them; (4) view the examination timetable for their classes; (5) view their courses and teaching survey summary and (6) view their publication records.

In the "services section", faculty members can: (1) view employment details, like salary, leave periods and other personal information; (2) make an appointments schedule, where they can enter their personal appointments;(3) view his/her training courses and official trips details; (4) use special facilities including change password and favorite links; (5) request a vehicle from administrative affairs department and follow up his/her request; (6) apply for road permits and follow up the request status; (7) apply for visa application and follow up the request status;(8) view onleave employee details(for administrative position); (9) request wireless services; (10) request help desk services; (11) Link to the university learning management systems and email system; (12) view their borrowed and overdue books from the library and (13)view traffic offences (linked to Royal Oman Police).

\section{The Sample}

Data was collected through a questionnaire from 75 faculty members at Sultan Qaboos University, a public academic institution in Oman. About $24 \%$ of the participants were lecturers, $44 \%$ were assistant professor, $24 \%$ associate professors and $8 \%$ were full professors. The majority of the participants, $68 \%$, were PhD holders; while $28 \%$ of them were MSc holders and $4 \%$ of them were BSc holders. About $80 \%$ of the participants were male. About $48 \%$ had at least two years of portal-use experience, and only $16 \%$ of them had less than one year portal-use experience. 


\section{Analysis \& Discussions}

\section{Analysis Methodology}

Three open-ended questions were developed and analyzed for this study. These research questions related to the usage, strengths and weaknesses of corporate portal independently. The qualitative questions were developed and analyzed based on Crano and Brewer (2002) and Miles and Huberman (1994). These researchers recommended several tools to analyze the qualitative data, including coding, and content analysis (a research tool that is used to make valid deductions from the research verbal data). The coding scheme was developed based on the relevant cited literature used in the background literature above. Frequency tables were developed to help draw inferences from the qualitative data (Miles and Huberman, 1994). Analysis was conducted separately question-byquestion.

\section{Usage Aspects of Corporate portal}

Examining the aspects of corporate portal use shed lights on what functions of the corporate portal were really perceived useful by the faculty members, and which functions were not receiving any attention. The faculty members, respondents, indicated that they use the portal for several purposes. It seems that corporate portal was used by faculty members mainly to have a single access to academic and personal information. All the respondents used the portal to access and obtain academic information (classes and exams timetables, students and advisees lists etc) as well as personal information (salary, leave, training courses, attended conferences etc) and library information(borrowed and overdue books). Some faculty members were using e-services such as online directory in the portal. They also use the portal to communicate with students through email (20\%), access university rules and regulations (cited by 16\%), and search for employees (cited only by $12 \%$ of respondents. Very few faculty members used the university portal to access and view external data. For instance, only $8 \%$ of respondents used the corporate portal to view their traffic offenses that is linked to Royal Oman Police.

\section{Strengths of Corporate Portal.}

Strengths are used to assess the benefits of the corporate portal. The results indicated that the strengths of corporate portal are related first to the information quality provided by the university portal (cited by $76 \%$ of faculty members); and second to the system quality (cited by $68 \%$ of faculty members). As indicated in Table 1 , the faculty members indicated that some of the strengths were related to information quality dimensions such as accessibility (highlighted by $24 \%$ of faculty members), information layout (16\%), information availability (12\%), general information quality (12\%), information sources reliability (8\%) and information timeliness (4\%). About the information quality provided by the portal, one of the faculty members highlighted that "Availability, reliability and accessing quality information" are the strengths of the portal. Another one said about the university portal that "It classifies the information given into sections which makes it easy to search for such information".

The dimensions of the corporate portal system quality that were raised by the faculty members as portal strengths were ease of use and access(reported by $36 \%$ of the faculty members), portal capabilities and variety of integrated services(16\%), system speed (12\%) and system quality(4\%). On portal system quality, one of the faculty members said "Easy access, easy language... ". Another one highlighted "Easiness, simplicity and clarity to use, variety of services...»

Some of the strengths of the portal perceived by the faculty members were related to recognized personal benefits such as improved information access (24\%), improved efficiency (20\%) and convenience $(12 \%)$. One of the respondents said the use of the portal is "very efficient and handy". 
Table 1: Strengths of Corporate Portal

\begin{tabular}{|l|l|l|l|l|l|}
\hline \multicolumn{2}{|c|}{ A )Information dimensions } & \multicolumn{2}{c|}{ B) System dimensions } & \multicolumn{2}{c|}{ C) Personal Benefits } \\
\hline $\begin{array}{l}\text { information } \\
\text { accessibility }\end{array}$ & $24 \%$ & $\begin{array}{l}\text { System ease of use } \\
\text { and access }\end{array}$ & $36 \%$ & $\begin{array}{l}\text { Improved information } \\
\text { access }\end{array}$ & $24 \%$ \\
\hline Information layout & $16 \%$ & $\begin{array}{l}\text { System integrated } \\
\text { services }\end{array}$ & $16 \%$ & improved efficiency & $20 \%$ \\
\hline $\begin{array}{l}\text { Information } \\
\text { availability }\end{array}$ & $12 \%$ & System speed & $12 \%$ & convenience & $12 \%$ \\
\hline Information quality & $12 \%$ & System quality & $4 \%$ & & \\
\hline Information reliability & $8 \%$ & & & & $56 \%$ \\
\hline Information timeliness & $4 \%$ & & & & \\
\hline Total & $76 \%$ & & $68 \%$ & & \\
\hline Note: numbers represents percentages of 75 participants & & \\
\hline
\end{tabular}

\section{Weaknesses of Corporate Portal}

Weaknesses are used to assess the disadvantages or the costs of using the corporate portal at the academic institution. Table 1 illustrates that majority of the identified weaknesses (64\%) were related to system dimensions: limited services (cited by $32 \%$ of the faculty members), slow access of external sources (12\%), off-campus accessibility (8\%), security (8\%) and complexity $(4 \%)$. One faculty members said:" Great difficulties and extremely slow response when accessing external websites linked to the portal". About the system limited services, one faculty member cited: "all requests within the university should be done in the portal as well as monitoring the progress of the requests". Another one said "... but I wish they include other services such as applying for vacation, requesting transportation services, etc." On system security, one respondent highlighted "I worry about the security of the information it contains".

Table 2: Weaknesses of Corporate Portal

\begin{tabular}{|l|l|l|l|l|l|}
\hline \multicolumn{2}{|c|}{ A ) System dimensions } & \multicolumn{2}{c|}{ B) Support Services } & \multicolumn{2}{c|}{ C) Information dimensions } \\
\hline $\begin{array}{l}\text { Limited scope \& } \\
\text { services }\end{array}$ & $32 \%$ & $\begin{array}{l}\text { No feedback forms to } \\
\text { submit queries }\end{array}$ & $12 \%$ & $\begin{array}{l}\text { Limited integrated } \\
\text { information }\end{array}$ & $8 \%$ \\
\hline $\begin{array}{l}\text { Slow access of } \\
\text { external sources }\end{array}$ & $12 \%$ & $\begin{array}{l}\text { No prompt support } \\
\text { services }\end{array}$ & $8 \%$ & $\begin{array}{l}\text { Information non- } \\
\text { timeliness }\end{array}$ & $4 \%$ \\
\hline No off-campus access & $8 \%$ & & & & \\
\hline security & $8 \%$ & & & & \\
\hline complexity & $4 \%$ & & & & $12 \%$ \\
\hline \multicolumn{7}{|l|}{ Total } & $64 \%$ & Total & & & \\
\hline \multicolumn{2}{|l|}{ Note: numbers represents percentages of 75 participants } \\
\hline
\end{tabular}

Other weaknesses of the university portal reported by the faculty members were related to supports services(20\%) such as no online support to communicate feedback or enquiries(12\%) and no prompt support services(8\%); and information quality 
$(12 \%)$ such as limited integrated information(8\%) and not up-to-date information(4\%). About this information issue, one respondent said: "It supposed to be one entry to all information that I need but currently not all information I need are available" ; another one said:" All SQU policies, rules and regulations should be there for easy access".

\section{Corporate Portal Success Factors}

As indicated above there are several frameworks to assess the internal characteristics of information systems that might be considered as internal strengths and weaknesses of specific information system and contribute to its success. One of these popular model is DeLone and McLean's
2003 IS success Model (DeLone and McLean, 2003).

This examination of the strengths and weaknesses revealed that the factors that were considered as weaknesses and strengths of the use of corporate portal, and contribute to the success of the corporate portal are similar to those proposed by (DeLone and McLean, 2003). This study indicated that factors that affect the usage of corporate portals are related to information quality, system quality and services quality; the study also showed that there are recognized net benefits of the corporate portal usage that further boost the use of corporate portal. Figure 1 illustrates an application of these study findings on DeLone and McLean 2003 Model.

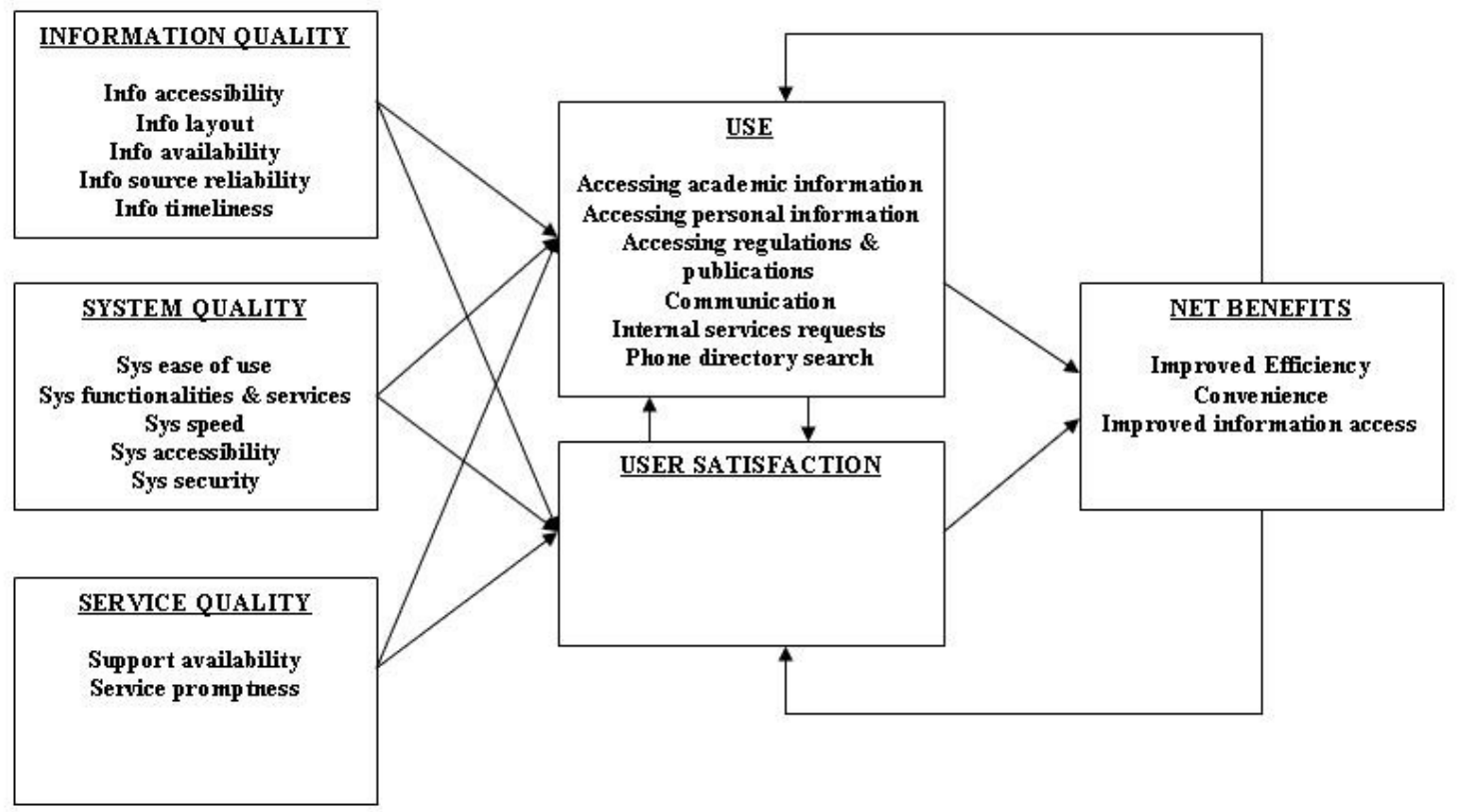

Fig 1. Corporate Portal Success Model

\section{Conclusion}

The role of corporate portal on consolidating an organization's internal and external information and knowledge repositories has been recognized by many organizations worldwide including academic institutions. Corporate portals have made their way in academic institutions. They are getting a wide-spread attention in the academic world (Bajec, 2005; Li and Wood, 2005).

This study provided some insights, for researchers and practitioners, on several aspects of corporate portal at an academic institution such as usage, strengths, weaknesses and success factors. This study illustrated a case of a deployment of 
corporate portal at an academic institution, Sultan Qaboos University (SQU). This study assessed the use of corporate portal in academic institution from the faculty members' perspective. The strengths and weaknesses analysis showed that the deployment of the corporate portal at $\mathrm{SQU}$ is relatively perceived as a success by the faculty members (the study respondents); the recognized benefits (strengths) of the corporate portal at this academic institution were more than the recognized costs (weaknesses) of the corporate portal (see Table 1 and Table 2). Comparing SQU portal to Deltor's corporate portal proposed architecture (Deltor, 2000). SQU portal provides a rich content space that provides information access to corporate data and documents. However, SQU portal is limited in terms of providing communication space, channels for conversation and negotiation; and very limited in providing coordination space, work flows and routines to support cooperative work action. SQU portal should integrate all needed information and services by users to really provide a "one single view" of the university's internal and external information and knowledge repositories.

The results indicated that the strengths of the university portal were related more to the information quality dimensions than system quality dimensions; whereas the weaknesses were related mainly to the system quality dimension and very few related to the information and the support services. Other strengths were related to the recognized personal benefits.

Moreover, this study provided some insights on the success factors of corporate portal as applied on DeLone and McLean (2003). The corporate portal success factors are related to information quality, system quality, service quality, which results in net benefits (see Figure 1). Despite the growing adoption rate of corporate portal, very limited studies have addressed and investigated the success and effectiveness of portal technologies (Masrek, 2007). Masrek (2007) found the portal system quality and service quality significantly contribute to the users satisfaction of corporate portal. This exploratory study provided initial detailed dimensions of system quality, service quality and system quality that contribute to the user satisfaction and usage of corporate portals, and a list of net benefits.

However, since this study was a qualitative investigation of corporate portal use at one academic institution, further investigations are needed to generalize these findings. Future investigations of corporate portals at academic institutions may include several types of users (such as students, faculty members, technical staff and administrative staff) with different demographics, several types of academic institutions and different countries. In addition, quantitative studies will improve the validity of the results and their generalization.

\section{References}

Aneja, A., Rowan, C., and Brooksby, B. 2000, 'Corporate Portal Framework For Transforming Content Chaos On Intranets,' Intel Technology Journal, Q1, 1-7.

Bajec, M. (2005), Educational Portals: A way to get integrated, user-centric university information systems, Web Portals: The new gateway to Internet information services, Tatnall, A. (ed.), Idea Group Publishing, Hershey, PA, USA..

Benbya, H., Passiante, G., and Belbaly N.A. (2004), 'Corporate Portal: A tool for knowledge management synchronization,' International Journal of Information Management, 24, 201-220.

Crano, W., and Brewer, M. (2002), Principles and Methods of Social Research, Lawrence Erlbaum Associates Publishers, NJ, USA.

DeLone, W. and McLean, E. (1992), 'Information Systems Success: The quest for dependant variable,' Information Systems Research, 3(1), 60-95.

DeLone, W. and McLean, E.R. (2003), 'The DeLone and McLean Model of Information Systems Success: A ten-year update,' Journal 
of Management Information Systems, 19(4), Detlor, B. (2000), 'The Corporate Portal as Information Infrastructure: Towards a framework for portal design,' International Journal of Information Management, 20(2), 91-101.

Gurugé, A. (2002a), 'Living and Breathing Portals,' Corporate Portals Empowered with XML and Web Services, 273-284.

Gurugé, A. (2002b), "Security, Scalability, and Speed," Corporate Portals Empowered with XML and Web Services, pp.115-151.

Li, S. and Wood, W. (2005), 'Portals in the Academic World: Are They Meeting Expectations?,' The Journal of Computer Information Systems, 45(4), 50-55.

Masrek, M. (2007), 'Measuring Campus Portal Effectiveness And The Contributing Factors,' Campus-Wide Information Systems, 24( 5), 342-354

Miles, M. B., and Huberman, A. M. (1994), Qualitative Data Analysis - An Expanded Source Book, Thousand Oaks, CA, USA.

Norris, G. and Duray, D. (2002), 'The Outside-in Portal,' Intelligence Enterprise, pp. 32-35.

Pearce, J. A. and Robinson, J. B. (2003), Strategic Management: Formulation, Implementation and Control , Irwin McGrawHill, NY, USA.

Rainer, J., Turban E. and Potter , R. (2007), Introduction to Information Systems: Supporting and transforming business, John Wiley \& Sons, Inc, USA.

Raol, J., Koong, K., Liu, L., and Yu, C. (2003), 'An Identification And Classification of Enterprise Portal Functions And Features,' Industrial Management \& Data Systems, 103(8/9), p. 693.

Roberts-Witt, S.(2000), 'Portal Pitfalls' Knowledge Management, pp. 42-46.
9-30.

Rose, J. (2003), 'The joys of enterprise portals,' Information Management, 37(5), 64-70.

Sabbaghi and Vaidyanathan. (2004), 'SWOT Analysis and Theory of Constraint in Information Technology Projects,' Information Systems Education Journal, 2(23).

Turban, E, Aronson, J \& Liang, T. (2005), Decision Support Systems and Intelligent Systems, Pearson Education Inc, NJ, USA.

Watson, J. \& Fenner J. (2000). 'Understanding portals,' Information Management Journal, 34(3), p.18. 